Original Article

\title{
DEVELOPMENT AND VALIDATION OF NOVEL RP-HPLC METHOD FOR SIMULTANEOUS ESTIMATION OF GABAPENTIN AND AMITRIPTYLINE HYDROCHLORIDE IN BULK AND PHARMACEUTICAL DOSAGE FORMS
}

\author{
SULTANA SHAIKH ${ }^{*}$, VANDANA JAIN ${ }^{2}$
}

${ }^{1}$ M. PHARM Student, Department of Quality Assurance, Oriental College of Pharmacy, Sanpada-Navi Mumbai, Maharashtra 400705, 2Department of Quality Assurance, Oriental College of Pharmacy, Sanpada-Navi Mumbai, Maharashtra 400705

Email: sultanaganimohd@gmail.com

Received: 18 Jan 2018, Revised and Accepted: 13 Feb 2018

\section{ABSTRACT}

Objective: To develop a novel, accurate, precise and linear reverse phase high performance liquid chromatographic (RP-HPLC) method for simultaneous quantitative estimation of gabapentin and amitriptyline hydrochloride in gabantip-at tablet and validate as per international conference on harmonization (ICH) guidelines and to perform the force degradation studies using the developed method.

Methods: In the present work, good chromatographic separation was achieved isocratically using a shim-pack HPLC C18 column (4.6 x 250 mm, $5 \mu$ m) and mobile phase consisting of $0.05 \mathrm{M}$ potassium dihydrogen orthophosphate $\mathrm{pH} 2.1$ adjusted with orthophosphoric acid and acetonitrile in the ratio (55:45), at flow rate $1 \mathrm{ml} / \mathrm{min}$ and column temperature $\left(25^{\circ} \mathrm{C}\right)$. The effluents obtained were monitored at $221 \mathrm{~nm}$ with the UV-visible detector.

Results: The retention time of gabapentin and amitriptyline hydrochloride was found to be 1.959 min and 4.221 min respectively. The linearity of gabapentin was found in the range of 720-1680 ppm and that for amitriptyline hydrochloride was found to be 24-56 ppm. The correlation coefficient for gabapentin and amitriptyline hydrochloride were 0.999 and 0.9963 respectively. The high recovery values (98\%- $101 \%$ ) indicate a satisfactory accuracy. The low percent relative standard deviation (\% RSD) values in the precision study reveals that the method is precise.

Conclusion: The developed method is novel, simple, precise, rapid, accurate and reproducible for simultaneous estimation of gabapentin and amitriptyline hydrochloride tablet dosage form. Hence the proposed method may find practical applications as a quality-control tool in the simultaneous analysis of the two drugs in combined dosage forms in quality-control laboratories.

Keywords: Gabapentin, Amitriptyline hydrochloride, RP-HPLC, Analysis, Validation, ICH

(C) 2018 The Authors. Published by Innovare Academic Sciences Pvt Ltd. This is an open access article under the CC BY license (http://creativecommons.org/licenses/by/4.0/) DOI: http://dx.doi.org/10.22159/ijap.2018v10i2.24842

\section{INTRODUCTION}

The IUPAC name of the gabapentin and amitriptyline hydrochloride is 2-[1-(aminomethyl) cyclohexyl] acetic acid and 3-(5,6dihydrodibenzo[2,1-b: 2',1'-f] 7-annulen-11-ylidene)-N,N-dimethylpropan-1-amine respectively, with molecular formula $\mathrm{C}_{9} \mathrm{H}_{17} \mathrm{NO}_{2}$ and $\mathrm{C}_{20} \mathrm{H}_{23} \mathrm{~N}$. HCl respectively and molecular weight 207.70 and 313.87 respectively $[1,2]$. Gabapentin is freely soluble in water, alkaline and acidic solution, sparingly soluble in methanol [1]. Amitriptyline hydrochloride is freely soluble in water and in alcohol [2]. The molecular structure of the drugs is given in fig. 1 .

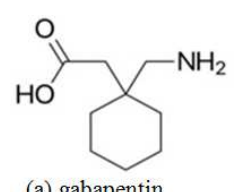

(a) gabapentin

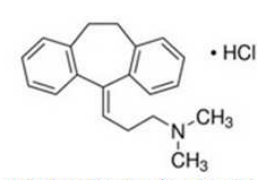

(b) amitriptyline hydrochloride
Fig. 1: Chemical structure of (a) gabapentin and (b) amitriptyline hydrochloride $[1,2]$

Gabapentin is an antiepileptic medication. It decreases pain and seizures by modulating calcium channel activity of the nerve cells [1] and amitriptyline is used in the treatment of depression and neuropathic pain. Amitriptyline increases the levels of chemical messengers in the brain that help in regulating the mood and treat depression [2, 3].

Combination therapy of gabapentin and amitriptyline hydrochloride is used for the treatment of neuropathic pain, depression and seizures. Combination of gabapentin and nortriptyline is also available in the market but the fact is amitriptyline is more effective in the treatment of endogenous depressive illness then nortriptyline [4] and it should remain in its position as the gold-standard antidepressant [5].
Literature survey reveals that various analytical and HPLC methods for estimation of gabapentin and amitriptyline hydrochloride were reported alone and in combination with other drugs in bulk, dosage forms, human plasma and in urine sample [1, 2, 6-16]. Also, HPLC methods have been reported for gabapentin and nortriptyline hydrochloride combination $[17,18]$ but to the best of our knowledge, there is no such reported HPLC analysis method for simultaneous estimation of gabapentin and amitriptyline hydrochloride combination. Hence, the aim of the present study was to develop a rapid and precise RP-HPLC method for the simultaneous estimation of gabapentin and amitriptyline hydrochloride in the combined dosage form and validate the developed method in accordance with ICH guidelines and also to perform the force degradation studies using the developed method. This novel validated method has applicability in the industry as well as academia.

\section{MATERIALS AND METHODS}

Gabapentin (99\% potency) and amitriptyline hydrochloride (99\% potency) were purchased from Chem dyes Corporation, RajkotGujarat. A commercial preparation gabantip-at tablet 'Sun Pharmaceutical Industries Ltd' containing gabapentin $300 \mathrm{mg}$ and amitriptyline hydrochloride $10 \mathrm{mg}$ used for analysis was procured from local market. HPLC grade solvents were purchased from Thomas Baker. RP-HPLC shimadzu (LC 2030) model with "Lab Solution" software was employed in this method. Analytical column used for the separation of analytes was shim-pack HPLC C18 $(250$ X $4.6 \mathrm{~mm}, 5 \mu \mathrm{m})$.

\section{Methods}

\section{Selection of wavelength}

The suitable wavelength for the HPLC analysis was determined by recording UV spectrums in the range of $190-380 \mathrm{~nm}$ for individual drug solutions of amitriptyline hydrochloride and gabapentin then 
overlapped. UV overlain spectra of both gabapentin and amitriptyline hydrochloride showed that both the drugs absorb appreciably at $221 \mathrm{~nm}$ and hence $221 \mathrm{~nm}$ was taken as a detection wavelength for HPLC analysis (fig. 2).

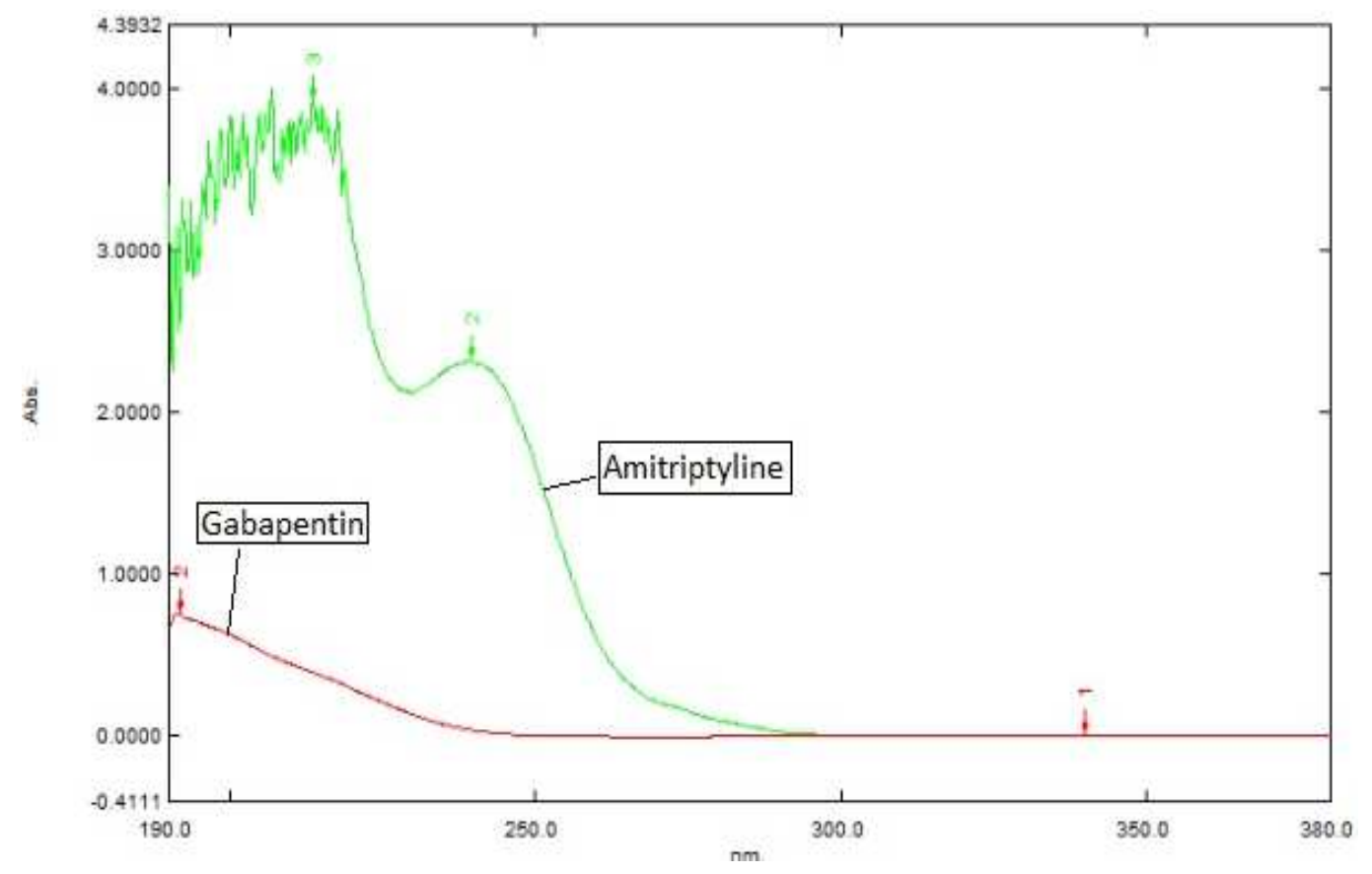

Fig. 2: UV overlap spectrum of amitriptyline hydrochloride and gabapentin

\section{Chromatographic conditions}

The method was developed using reverse phase, shim-pack HPLC C18 column ( $250 \times 4.6 \mathrm{~mm}, 5 \mu \mathrm{m})$. The runtime was of $7 \mathrm{~min}$. The mobile phase used was $0.05 \mathrm{M}$ potassium dihydrogen orthophosphate $\mathrm{pH} 2.1$ adjusted with orthophosphoric acid and acetonitrile in the ratio $(55: 45)$ at a flow rate of $1.0 \mathrm{ml} / \mathrm{min}$, column temperature $\left(25^{\circ} \mathrm{C}\right)$ and a detection wavelength of $221 \mathrm{~nm}$ using a UV-visible detector.

\section{Preparation of 0.05 M phosphate buffer (pH 2.1)}

About $6.80 \mathrm{~g}$ of potassium dihydrogen orthophosphate was accurately weighed and dissolved in $950 \mathrm{ml}$ of water. The pHwas adjusted to 2.1 with orthophosphoric acid and the volume was made up to $1000 \mathrm{ml}$ in a volumetric flask. The solution was then filtered using $0.45 \mu$ membrane filter.

\section{Preparation of standard solution}

$100 \mathrm{mg}$ of amitriptyline hydrochloride and $300 \mathrm{mg}$ of gabapentin standard were accurately weighed and transferred into $100 \mathrm{ml}$ volumetric flask respectively. About $70 \mathrm{ml}$ solvent was added, sonicated to dissolve and diluted up to the mark using a solvent (1000 ppm of amitriptyline hydrochloride and $3000 \mathrm{ppm}$ of gabapentin). The final concentration of amitriptyline hydrochloride and gabapentin were made to $40 \mathrm{ppm}$ and $1200 \mathrm{ppm}$ respectively by suitable dilutions.

\section{Preparation of sample solution}

10 tablets were weighed and powdered. The quantity of powder equivalent to $10 \mathrm{mg}$ of amitriptyline hydrochloride and $300 \mathrm{mg}$ of gabapentin was transferred into a $100-\mathrm{ml}$ volumetric flask. About $70 \mathrm{ml}$ solvent was added and the solution was sonicated for 30 min with intermittent shaking. The volume was made up using the solvent, mixed and filtered through $0.45 \mu$ PVDF filter. Final concentrations of amitriptyline hydrochloride and gabapentin were made to $40 \mathrm{ppm}$ and $1200 \mathrm{ppm}$ respectively with suitable dilution.

\section{Forced degradation studies}

Forced degradation is the process of subjecting drug compounds to extreme chemical and environmental conditions to determine product breakdown levels and preliminary degradation kinetics, and to identify potential degradation products. They are used to facilitate the development of analytical methodology, to gain a better understanding of active pharmaceutical ingredient and drug product stability, and to provide information about degradation pathways and degradation products. The study involves acid and alkali hydrolysis wherein sample solution was treated with $0.1 \mathrm{~N} \mathrm{HCl}$ and $0.1 \mathrm{~N} \mathrm{NaOH}$ respectively at room temperature for $2 \mathrm{~h}$. Oxidative degradation studies involved $30 \% \mathrm{v} / \mathrm{v} \mathrm{H}_{2} \mathrm{O}_{2}$ treatment of sample solution at room temperature for $2 \mathrm{~h}$. The samples were placed in hot air oven at $105{ }^{\circ} \mathrm{C}$ for $1 \mathrm{~h}$ to study thermal degradation. For photolytic stress studies, samples were exposed in photostability chamber for $5 \mathrm{~h}$. The sample was placed in a humidity chamber at 25 ${ }^{\circ} \mathrm{C}$ and $80 \%$ RH (relative humidity) for $24 \mathrm{~h}$ to study degradation by humidity $[19,20]$.

\section{RESULTS AND DISCUSSION}

\section{Method development}

A reverse phase HPLC method was developed keeping in mind the system suitability parameters i.e. resolution factor between peaks, tailing factor, a number of theoretical plates, runtime and the costeffectiveness. The developed optimized method resulted in the elution of gabapentin at $1.9 \mathrm{~min}$ and amitriptyline hydrochloride at 4.2 min. Fig. 3, 4 and 5 represent chromatograms of the blank solution, gabapentin standard solution and amitriptyline hydrochloride standard solution respectively.

The total run time was $7 \mathrm{~min}$. System suitability tests are an integral part of method development and are used to ensure adequate performance of the chromatographic system. Retention time, a number of theoretical plates, peak resolution and peak tailing factor were evaluated for six replicate injections of the standard working concentration. The results given in table 1 were within acceptable limits [21]. 
$\mathrm{mV}$

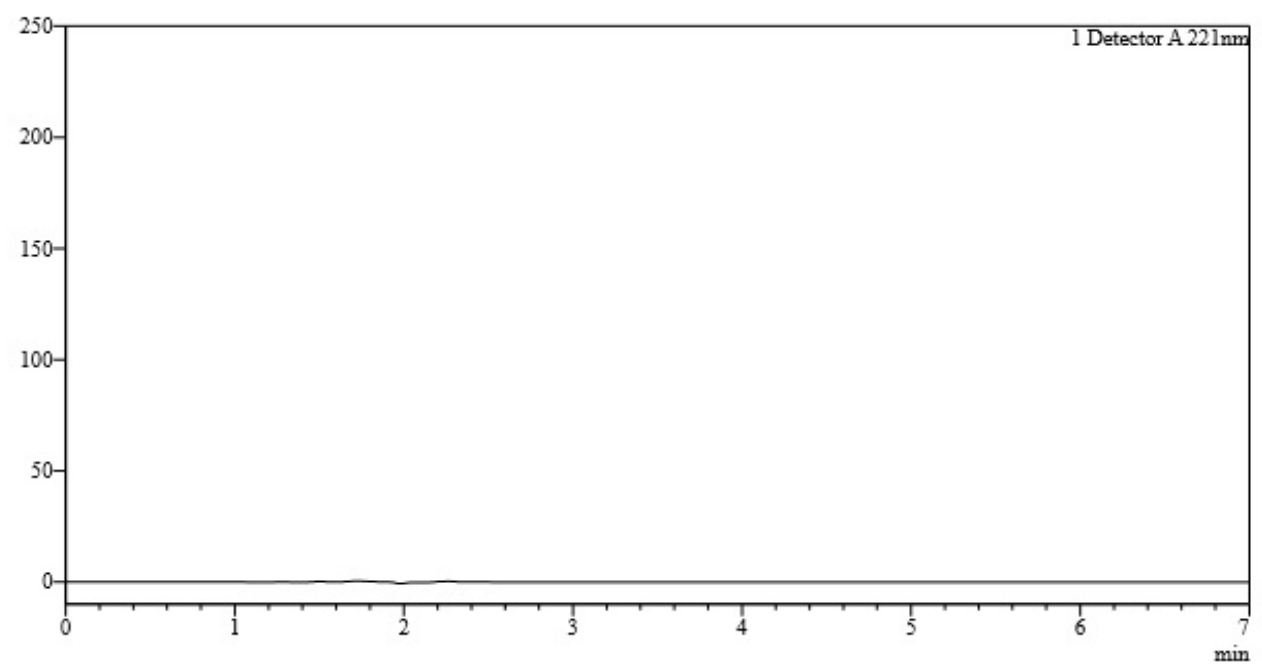

Fig. 3: Typical chromatogram of blank solution

$\mathrm{mV}$

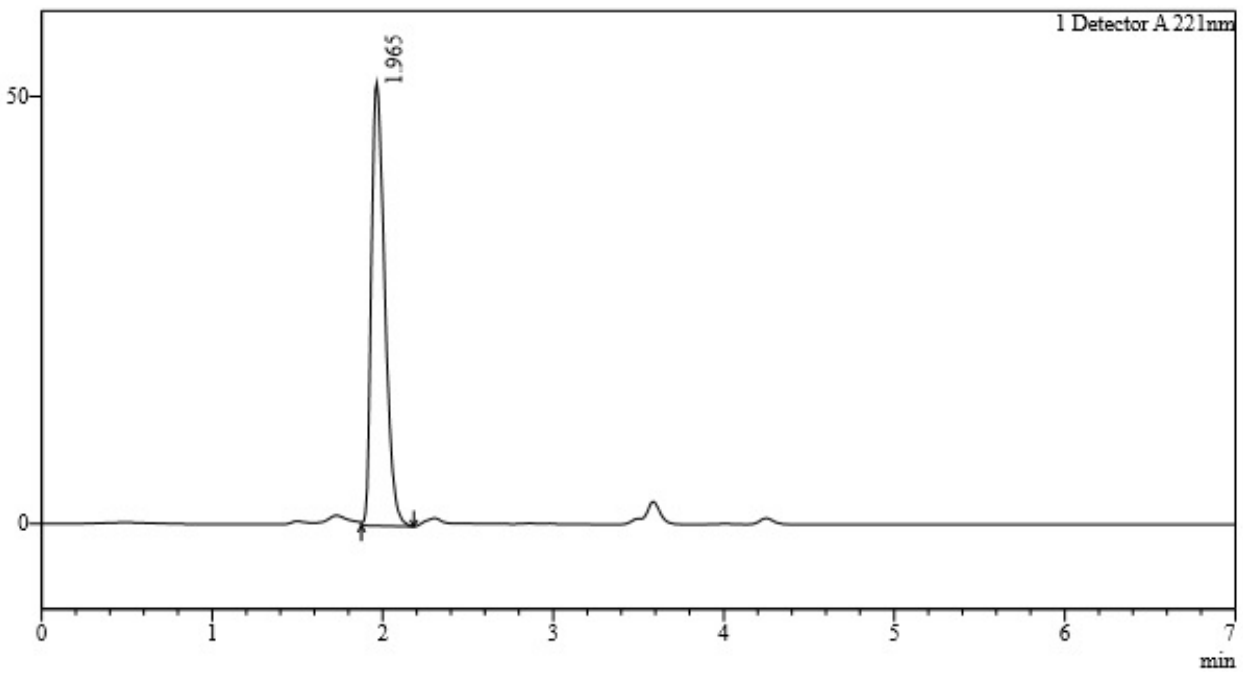

Fig. 4: Typical chromatogram of gabapentin standard solution

$\mathrm{mV}$

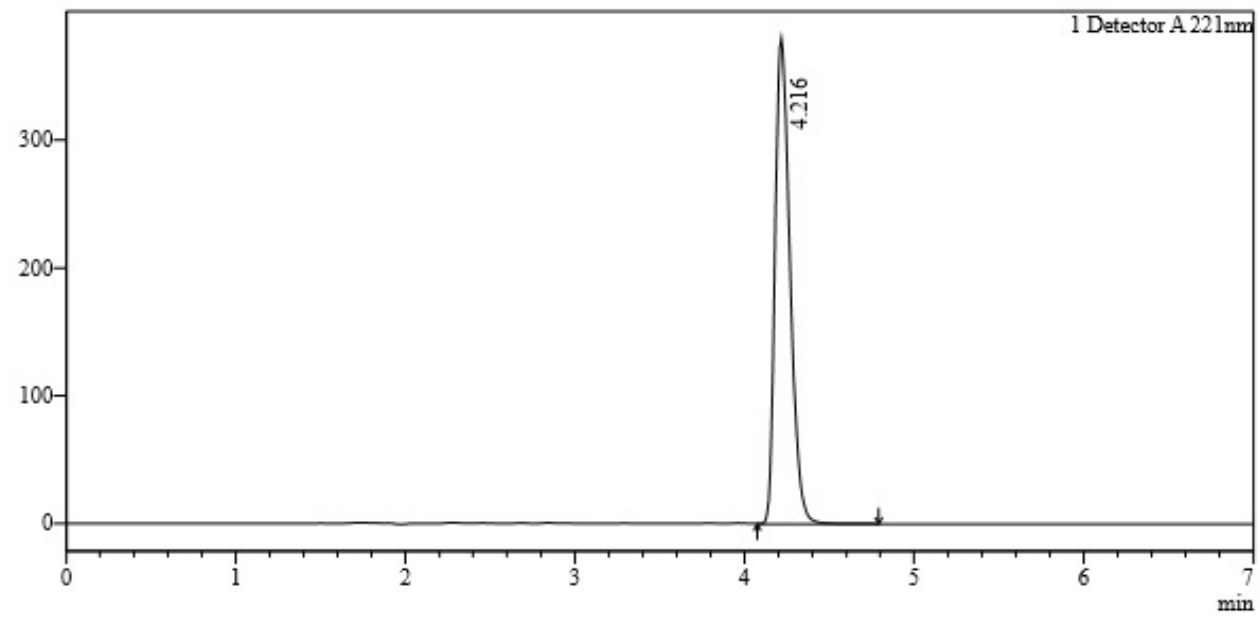

Fig. 5: Typical chromatogram of amitriptyline hydrochloride standard solution 
Table 1: Results of system suitability studies

\begin{tabular}{lll}
\hline Parameters & Acceptance limits & Amitriptyline hydrochloride \\
\hline Retention time & - & 4.221 min \\
Resolution factor & Not less than 2 & 13.575 \\
Number of Theoretical plate & Not less than 2000 & 9450 \\
Tailing factor & Not more than 2 & 1.959 min \\
\hline
\end{tabular}

In order to test the applicability of the developed method to a commercial formulation, 'gabantip-at' tablets were chromatographed at working concentration and it is shown in fig. 6 . The sample peaks were identified by comparing the relative retention times with standard drugs (fig 4-5). System suitability parameters were within the acceptance limits, ideal for the chromatographed sample. Integration of separated peak area was done and each drug concentration was determined by using the peak area concentration relationship obtained in the standardization step. The protocol affords reproducible quantification of the two drugs with an error less than $10 \%$, which is the standard level in any pharmaceutical quality control.

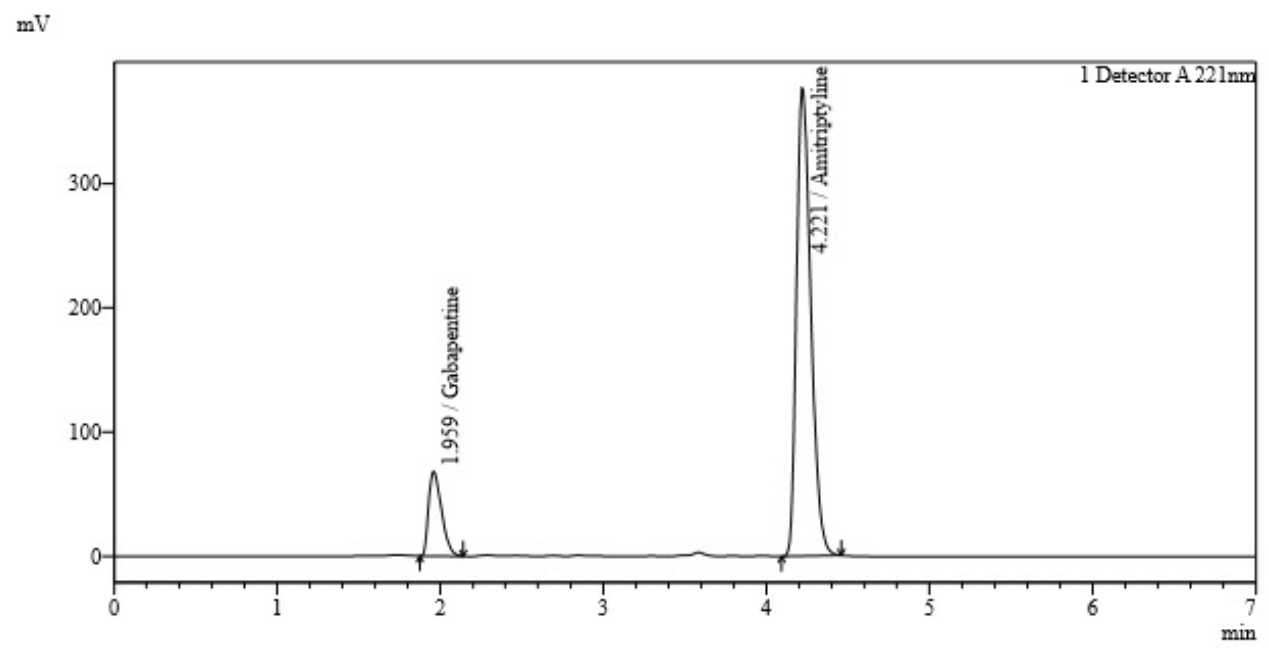

Fig. 6: Typical chromatogram of the sample

\section{Method validation}

Validation of the analytical method is the process that establishes by laboratory studies in which the performance characteristics of the method meet the requirements for the intended analytical application. HPLC method developed was validated according to ICH guidelines [22] for validation of analytical procedures. The method was validated for the parameters like linearity, accuracy, system precision, method precision, robustness, limit of detection and limit of quantitation.

\section{Specificity}

Fig. 3-6 for a blank solution, standard drug solutions and sample chromatogram reveal that the peaks obtained in the standard solutions and sample solution at working concentrations are only because of the drugs as blank has no peak at the retention time of gabapentin and amitriptyline hydrochloride. Accordingly, it can be concluded that the method developed is said to be specific [23].

\section{Precision}

\section{System precision}

Six replicate injections of the standard solutions at working concentration showed percent relative standard deviation (\% RSD) less than 2 concerning peak area for both the drugs, which indicates the acceptable reproducibility and thereby the precision of the system $[24,25]$. System precision results are tabulated in table 2.

\section{Method precision}

Method precision was determined by performing the assay of the sample under the test of repeatability (intraday precision) at working concentration. Six injections of the sample from the same homogeneous mixture at working concentration showed \% RSD less than 2 concerning $\%$ assay for both the drugs which indicate that the method developed is method precise by the test of repeatability $[24,25]$ and hence can be understood that the method gives consistently reproducible results (table 3).

Table 2: System precision results

\begin{tabular}{lll}
\hline S. No. & Peak area of amitriptyline hydrochloride (40 $\mathbf{p p m})$ & Peak area of gabapentin (1200 ppm) \\
\hline 1 & 2325911 & 382152 \\
2 & 2331400 & 382984 \\
3 & 2341426 & 386194 \\
4 & 2338850 & 385431 \\
5 & 2343853 & 387636 \\
6 & 2341335 & 386683 \\
Average & 2337129 & 385180 \\
SD & 6971 & 2162 \\
\%RSD & 0.30 & 0.56 \\
\hline
\end{tabular}

\#SD: Standard deviation, \#\% RSD: Percent relative standard deviation 
Table 3: Method precision results

\begin{tabular}{lll}
\hline S. No. & Amitriptyline hydrochloride \% assay & Gabapentin \% assay \\
\hline 1 & 99.31 & 99.70 \\
2 & 99.98 & 99.20 \\
3 & 100.92 & 100.20 \\
4 & 99.48 & 100.20 \\
5 & 100.35 & 99.70 \\
6 & 99.58 & 100.30 \\
Average & 100.10 & 99.90 \\
SD & 8.40 & 4.30 \\
\%RSD & 0.84 & 0.43 \\
\hline
\end{tabular}

\#SD: Standard deviation, \#\%RSD: Percent relative standard deviation

\section{Linearity}

Standard solutions of amitriptyline hydrochloride and gabapentin at different concentrations level $(60 \%, 80 \%, 100 \%, 120 \%$, and $140 \%$ ) were prepared in triplicates. Calibration curves were constructed by plotting the concentration level versus corresponding peak areas for both the drugs. The results show an excellent correlation between peak areas and concentrations level within the tested concentration range of $24-56 \mathrm{ppm}$ for amitriptyline hydrochloride and 720-1680 ppm for gabapentin (table 4). The correlation coefficients were greater than 0.99 for both the drugs, which meet the method validation acceptance criteria $[24,25]$ and hence the method is said to be linear for both the drugs (fig. 7-9).

Table 4: Data for linearity studies

\begin{tabular}{llll}
\hline \% level & Amitriptyline hydrochloride & & Gabapentin \\
\cline { 2 - 4 } & Concentration in ppm & Peak area & Concentration in ppm \\
\hline 60 & 24 & 1420116 & 720 \\
80 & 32 & 1951615 & 960 \\
100 & 40 & 2325911 & 1200 \\
120 & 48 & 2834560 & 1440 \\
140 & 56 & 3389963 & 1680 \\
Slope & 60283 & & 282.36 \\
Y intercept & -26887 & & 40557 \\
Correlation Coefficient & 0.9963 & & 0.999 \\
\hline
\end{tabular}

uV

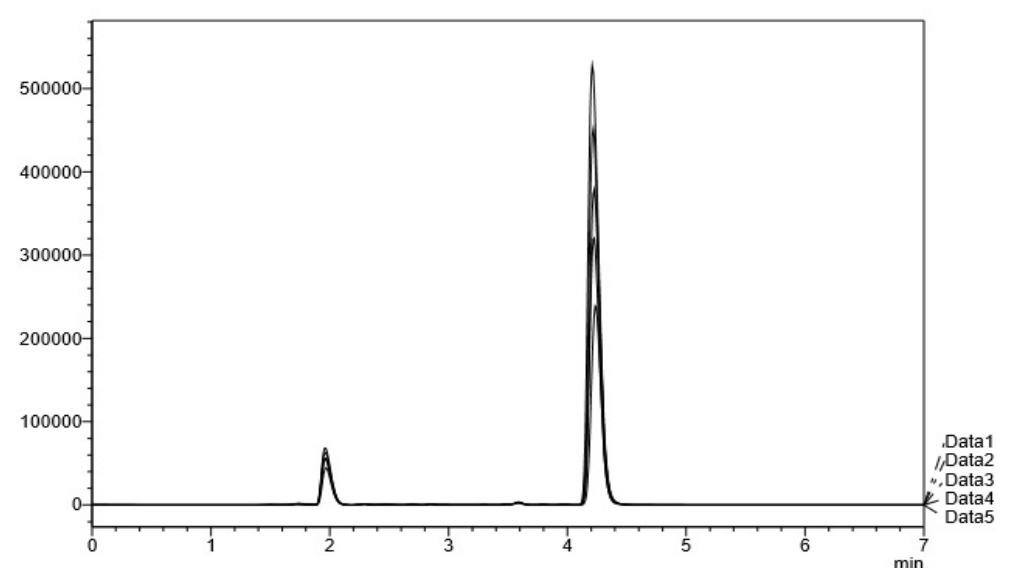

Fig. 7: Chromatogram of gabapentin and amitriptyline hydrochloride (five different concentration overlapped for linearity study)

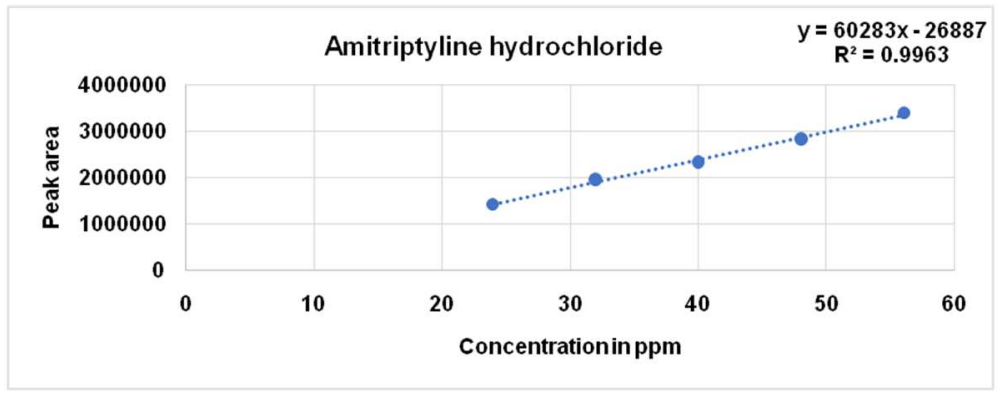

Fig. 8: Calibration curve of amitriptyline hydrochloride 


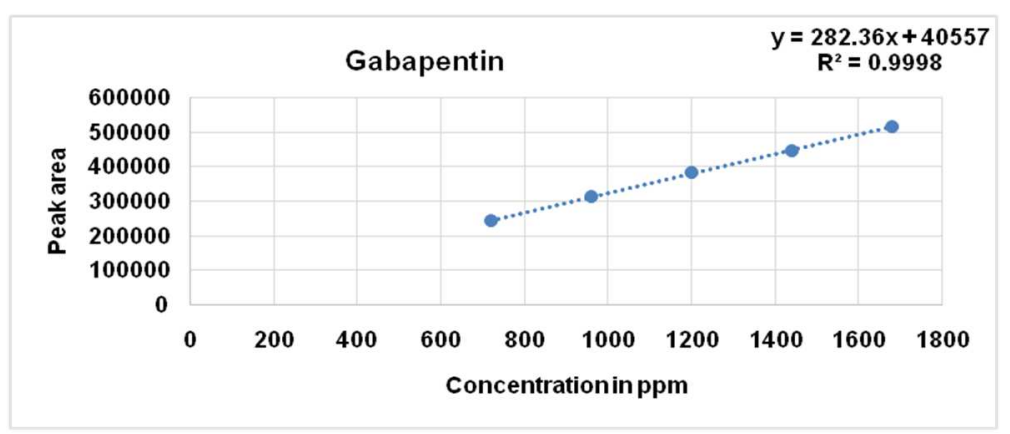

Fig. 9: Calibration curve of gabapentin

\section{Accuracy}

Accuracy was determined by means of recovery experiments, by the determination of $\%$ mean recovery of both the drugs in the formulation at three different levels (80-120\%). At each level, three determinations were performed. Percent mean recovery was calculated as shown in table 5 and 6 . The accepted limits of mean recovery are 98\%-102\% and all observed data were within the required range, which indicates good recovery values, affirming the accuracy of the method developed [24, 25].

Table 5: Accuracy data for gabapentin

\begin{tabular}{|c|c|c|c|c|c|c|}
\hline $\begin{array}{l}\text { Level (\%) }(n=3) \\
\text { (gabapentin) }\end{array}$ & $\begin{array}{l}\text { Sample } \\
\text { [ppm] }\end{array}$ & $\begin{array}{l}\text { Standard added } \\
\text { [ppm] }\end{array}$ & $\begin{array}{l}\text { Actual amount } \\
\text { [ppm] }\end{array}$ & $\begin{array}{l}\text { Total area found } \\
\text { [average] } n=3\end{array}$ & $\begin{array}{l}\text { Amount recovered } \\
\text { [ppm] }\end{array}$ & $\begin{array}{l}\% \\
\text { recovery }\end{array}$ \\
\hline 80 & 600 & 480 & 1080 & 350140 & 1096.41 & 101.51 \\
\hline 100 & 600 & 600 & 1200 & 382152 & 1209.78 & 100.81 \\
\hline 120 & 600 & 720 & 1320 & 412115 & 1315.90 & 99.68 \\
\hline
\end{tabular}

\#n: Number of injections

Table 6: Accuracy data for amitriptyline hydrochloride

\begin{tabular}{|c|c|c|c|c|c|c|}
\hline $\begin{array}{l}\text { Level }(\%)(n=3) \text { (amitriptyline } \\
\text { hydrochloride) }\end{array}$ & $\begin{array}{l}\text { Sample } \\
\text { (ppm) }\end{array}$ & $\begin{array}{l}\text { Standard added } \\
\text { (ppm) }\end{array}$ & $\begin{array}{l}\text { Actual amount } \\
\text { [ppm] }\end{array}$ & $\begin{array}{l}\text { Total area } \\
\text { found } \\
\text { [average] } n=3\end{array}$ & $\begin{array}{l}\text { Amount } \\
\text { recovered } \\
\text { [ppm] }\end{array}$ & $\begin{array}{l}\text { \% } \\
\text { recovery }\end{array}$ \\
\hline 80 & 20 & 16 & 36 & 2166897 & 36.39 & 101.08 \\
\hline 100 & 20 & 20 & 40 & 2338911 & 39.24 & 98.11 \\
\hline 120 & 20 & 24 & 44 & 2632705 & 44.11 & 100.26 \\
\hline
\end{tabular}

\#n: Number of injections

\section{Robustness}

To determine the robustness of the developed method, experimental conditions were deliberately altered, and the system suitability parameter retention time and peak area were evaluated. The solution was prepared as per the test method described earlier and injected at different variable conditions like flow rate $\left(0.8 \mathrm{ml} / \mathrm{min}\right.$ and $1.2 \mathrm{ml} / \mathrm{min}$.), column temperature $\left(23{ }^{\circ} \mathrm{C}\right.$ and $27^{\circ} \mathrm{C}$ ) and detection wavelength $(220 \mathrm{~nm}$ and $222 \mathrm{~nm})$. Robustness data clearly shows that the proposed method is robust at small but deliberate change $[24,25]$. Robustness data are given in table 7.

Table 7: Robustness data for amitriptyline hydrochloride and gabapentin

\begin{tabular}{llllc}
\hline Experiment & \multicolumn{2}{l}{ Amitriptyline hydrochloride } & \multicolumn{2}{l}{ Gabapentin } \\
\cline { 2 - 5 } & $\begin{array}{l}\text { Retention time } \\
\text { (min) }\end{array}$ & $\begin{array}{l}\text { Average area } \\
(\mathbf{n = 3})\end{array}$ & $\begin{array}{l}\text { \% assay } \\
\text { Retention time } \\
\text { (min) }\end{array}$ \\
\hline Minus flow $[0.8 \mathrm{ml} / \mathrm{min}]$ & 4.378 & 2333114 & 98.98 & 2.095 \\
(n=3)
\end{tabular}

\#n: Number of injections

\section{Sensitivity}

The sensitivity of measurement of amitriptyline hydrochloride and gabapentin by use of the proposed method was estimated in terms of the limit of quantitation (LOQ) and limit of detection (LOD). LOQ and LOD were calculated by the use of the equations LOD $=3.3 \sigma / \mathrm{S}$ and $L O Q=10 \sigma / S$ where $\sigma$ is the standard deviation of intercepts of calibration plots and $S$ is the average of the slopes of the corresponding calibration plot.

The LOD for amitriptyline hydrochloride and gabapentin were found to be $0.26 \mathrm{ppm}$ and $41.90 \mathrm{ppm}$ respectively, while LOQ for 
amitriptyline hydrochloride and gabapentin were found to be 0.81 ppm and 126.97 ppm respectively.

\section{Solution stability}

Sample solution was injected at different time interval and \% assay was calculated.
The sample solution was found to be stable at room temperature if protected from light and moisture.

The solution stability of $72 \mathrm{~h}$ indicated that the sample solution can be used over a period of $72 \mathrm{~h}$ without any degradation of the solution (table 8).

Table 8: Solution stability data of amitriptyline hydrochloride and gabapentin

\begin{tabular}{lll}
\hline Time & \% assay (amitriptyline hydrochloride) & \% assay (gabapentin) \\
\hline Initial & 99.16 & 99.15 \\
After 1 d & 99.14 & 99.11 \\
After 2 d & 99.17 & 99.17 \\
After 3 d & 99.15 & 99.16 \\
\hline
\end{tabular}

\section{Forced degradation studies}

Forced degradation studies were performed to demonstrate the stability of the sample in different stressed conditions. The conditions used were acid and base hydrolysis, dry heat, oxidation, humidity and photolysis. The $\%$ assay of the amitriptyline hydrochloride and gabapentin with respect to untreated samples and \% assay results obtained after treating the samples with various stress conditions had a difference which was within the acceptable limits. There was slightly higher degradation in UV, heat and humidity treated sample with respect to amitriptyline hydrochloride which indicates that it is unstable in these conditions and thus amitriptyline hydrochloride should be protected from light, moisture and direct heat, whereas it is relatively stable in acidic and basic condition. Gabapentin undergoes some amount of degradation in UV treated sample and base treated sample, slightly higher degradation when treated with hydrogen peroxide. Gabapentin is stable in acidic condition. As there was no interference observed from any components of the pharmaceutical dosage form or degrading products, hence it concludes that the developed method is stability indicating a method for simultaneous estimation of amitriptyline hydrochloride and gabapentin in the pharmaceutical dosage form. The data for forced degradation are tabulated in table 9 .

Table 9: Data for force degradation study

\begin{tabular}{lllll}
\hline Condition & \multicolumn{2}{l}{ Amitriptyline hydrochloride } & Gabapentin \\
\cline { 2 - 5 } & \% assay & \% Difference w. r. t. control & \% assay & \% Difference w. r. t. control \\
\hline Untreated sample & 99.31 & NA & 91.70 & NA \\
Acid treated sample & 98.31 & 1.2 & 99.20 & 0.5 \\
Base treated sample & 98.11 & 01 & 96.70 & 03 \\
Peroxide treated sample & 98.31 & 04 & 91.70 & 08 \\
Heat treated sample & 95.31 & 11 & 98.20 & 1.5 \\
UV treated sample & 88.29 & 07 & 97.70 & 02 \\
Humidity treated sample & 92.31 & 98.70 & 01 \\
\hline
\end{tabular}

The results obtained from above set of observations prove that the method is useful in the qualitative and quantitative analysis of the drugs from the synthetic mixture and tablet formulation. Moreover, various analytical and HPLC methods for estimation of gabapentin and amitriptyline hydrochloride were reported alone and in combination with other drugs [1,2, 6-18] but as yet there is no reported HPLC analysis method for simultaneous estimation of gabapentin and amitriptyline hydrochloride combination and the novel method developed in this report is the first of its kind. This study reveals that the estimations can be done within $72 \mathrm{~h}$ at least, without having any detrimental effect on drug stability. The developed method is based on the use of a very economical solvent, had short chromatographic time and hence can be performed with ease.

\section{CONCLUSION}

A validated RP-HPLC method was developed for simultaneous estimation of gabapentin and amitriptyline hydrochloride in the pharmaceutical dosage form. This novel HPLC method found to be simple, precise, accurate and had a short chromatographic time. The solution stability of $72 \mathrm{~h}$ indicated that the sample solution can be used over a period of $72 \mathrm{~h}$ without any degradation of the solution. The developed method was validated as per the ICH guidelines and the results obtained were well within the limits. Percent recovery and estimated concentration of active ingredient in pharmaceutical formulations showed that the amount of drug present is consistent with the label claim. Hence the proposed method was found to be satisfactory and can be applied for the analysis of gabapentin and amitriptyline hydrochloride in pharmaceutical dosage forms. This method can be utilized in routine quantitative and qualitative analysis of gabapentin and amitriptyline hydrochloride in pharmaceutical formulation and to study degradation pathway. These results indicate that the proposed method may find practical applications as a qualitycontrol tool in the simultaneous analysis of the two drugs in combined dosage forms in quality-control laboratories.

\section{AUTHORS CONTRIBUTIONS}

All the authors have contributed equally

\section{CONFLICT OF INTERESTS}

Declared none

\section{REFERENCES}

1. Syed S, Mohammed M, Ehab A, Mohammed A. Validation of an isocratic HPLC assay of gabapentin in pharmaceutical formulations and stress test for stability of drug substance. Pharm Lett 2011;3:342-50.

2. Rabie S, Ashraf MA. RP-HPLC determination of amitriptyline hydrochloride in tablet formulations and urine. Asian J Res Chem 2011;4:24-7.

3. Hyttel J, Christensen AV, Fjalland B. Neuropharmacological properties of amitriptyline, nortriptyline and their metabolites. Acta Pharmacol Toxicol (Copenh) 1980;47:53-7.

4. John TR, Leahy MR, Ian CM, Westhead TT. A comparison of nortriptyline and amitriptyline in depression. Br J Psychiatry 1965;111:1101-3.

5. Corrado B, Matthew H. Amitriptyline v. the rest: still the leading antidepressant after $40 \mathrm{y}$ of randomised controlled trials. $\mathrm{Br} \mathrm{J}$ Psychiatry 2001;178:129-44.

6. Das B. Estimation of gabapentin in human plasma using LCMS/MS method. Asian J Pharm Clin Res 2013;6 Suppl 3:213-6. 
7. Rao B, Maqdoom F, Nikalje AP. Determination of gabapentin in bulk drug and in pharmaceutical dosage form by HPLC method. J Chil Chem Soc 2009;54:424-7.

8. Faraat A, Singha GN, Sahua P, Nagarab R, Nagara M, Tyagi A. Application of an LC/HPLC method development and validation for the simultaneous estimation of amitriptyline hydrochloride and chlordiazepoxide in tablet dosage form by using a reverse phase technique. Pharm Lett 2015;7:172-7.

9. Srikantha D, Raju R. Method development and validation of chlordiazepoxide and amitriptyline hydrochloride in pharmaceutical formulations by RP-HPLC. Asian J Biomed Pharm Sci 2014;4:8-14.

10. Lakshmi B. RP-HPLC method development for the quantification of gabapentin in formulations. Exp Int J Sci Technol 2012;2:84-92.

11. Karchaliya CV, Patel PB. Development and validation of analytical methods for simultaneous estimation of amitriptyline hydrochloride and methylcobalamin in their tablet dosage form by UV spectrophotometric method. PharmaTutor Mag 2015;3:46-50.

12. Galande VR, Baheti KG, Dehghan MH. UV-visible spectrophotometric method for estimation of gabapentin and methylcobalamin in bulk and tablet. Int J ChemTech Res 2010;2:695-9.

13. Rabie S, Darwish M, Mohamed F, Hamdi A. New HPLC method to detect amitriptyline in the blood of rats on combination treatment. Int J Chem Anal Sci 2013;4:120-4.

14. Patel S, Patel NJ. Spectrophotometric and chromatographic simultaneous estimation of amitriptyline hydrochloride and chlordiazepoxide in tablet dosage forms. Indian J Pharm Sci 2009;71:472-6.

15. Saleh T. Assay of four psychotropic drugs chlorpromazine, clomipramine, amitriptyline and nortriptyline in tablets by a single HPLC method. Int J Pharm Pharm Sci 2016;8:182-8.
16. Sevak R, Sevak AD, Manan R, Vyas PJ. Analytical method development and validation for amitriptyline $\mathrm{HCl}$ (psychoactive drug) using HPLC instrument. IOSR J Appl Chem 2017;10:77-80.

17. Patel Y, Patel MB, Patel NK, Sakhreliya B. Development and validation of analytical method for simultaneous estimation of gabapentin and nortriptyline hydrochloride in pharmaceutical dosage form. J Pharm Sci Bio-Sci Res 2015;5:434-43.

18. Shah A, Kothari C, Patel N. Concurrent estimation of gabapentin and nortriptyline hydrochloride in their combined dosage form using OPA- $\beta$-mercaptoethanol derivatization by spectrophotometric and spectrofluorimetric methods. Curr Pharm Anal 2017;13:241-9.

19. Rawat T, Pandey IP. Forced degradation studies for drug substances and drug products-scientific and regulatory considerations. J Pharm Sci Res 2015;7:238-41.

20. ICH, Stability testing of new drug substances and products (Q1AR2), International Conference on Harmonization, IFPMA Geneva; 2003.

21. Vemula VR, Sharma PK. RP-HPLC method development and validation for simultaneous estimation of diclofenac and tolperisone in tablet dosage form. Asian J Pharm Clin Res 2013;6 Suppl 3:186-9.

22. International Conference on Harmonization of Technical Requirements for Registration of Pharmaceuticals for Human use. Validation of Analytical Procedures: Text and Methodology ICH Q2(R1); 2005.

23. Sarat M, Murali PK, Rambabu C. Development and validation of RPHPLC method for simultaneous estimation of amlodipine besylate and benazepril $\mathrm{Hcl}$ in tablet dosage form. Int J Curr Pharm Res 2012;4:80-4.

24. FDA, Guidance R. Validation of chromatographic methods. centre for drug evaluation and research (CDER), Food and Drug Administration; 1994. p. 2.

25. FDA, ORA validation and verification guidance for human drug analytical methods. Food and Drug Administration; 2003. p. 1. 